\title{
A Review on Freedom and Authority in Theories of John Locke and Thomas
}

\section{Hobbes}

\author{
John Locke ve Thomas Hobbes'un Teorilerinde Özgürlük ve Otorite Sorunu Üzerine Bir \\ Inceleme
}

Aslıhan ÇOBAN BALCI ${ }^{1}$

\begin{tabular}{l} 
Article Info \\
\hline Article History: \\
Date Submitted: 24.10 .2019 \\
Date Accepted: 08.01 .2020 \\
Jel Classification: \\
B10,B20,P10, P16 \\
Keywords: \\
Freedom, \\
Authority, \\
J. Locke, \\
T. Hobbes
\end{tabular}

\begin{abstract}
This article tackles with the questions of freedom and authority in the thoughts of J. Locke and T. Hobbes. J. Locke is mostly known as the father of classical liberal thought whereas T. Hobbes is known with his famous work Leviathan within which he questions the source of sovereignty and made a focus on a strong sovereign. Both thinkers are social contract thinkers. However, their descriptions on state of nature are completely different. In this work, not only the mere concepts of freedom and authority but also legitimate power, law, despotism and consent will be discussed in their thought as such they are very related to the freedom and authority. To that end, first the relationship between state and individual will be addressed. Second the relationship between law and liberty will be mentioned. Then the concepts of political power and authority will be overviewed. Lastly the main questions associated with freedom and authority will be evaluated. At the end, it is supposed to delineate a general assessment about these two thinkers on their critical concepts, freedom and authority.
\end{abstract}

\section{Özet}

$\mathrm{Bu}$ makalede, J. Locke ve T. Hobbes'un düşüncelerinde özgürlük ve otorite soruları ele alınmaktadır. J. Locke çoğunlukla klasik liberal düşüncenin babası olarak bilinir; oysa T. Hobbes meşhur çalışması Leviathan ile birlikte egemenliğin kaynağını sorgular ve güçlü bir egemenliğe odaklanır. Her iki düşünür de sosyal sözleşme düşünürleridir. Bununla birlikte, doğa durumuna ilişkin açıklamaları tamamen farklıdır. Bu çalışmada, yalnızca özgürlük ve otorite kavramları değil, aynı zamanda meşru iktidar, hukuk, despotizm ve rıza kavramları da, özgürlük ve otorite düşünceleri de tartışılacaktır. Bu amaçla, önce devlet ile birey arasındaki ilişki ele alınacaktır. İkinci olarak hukuk ve özgürlük arasındaki ilişkiye değinilecektir. Daha

\footnotetext{
${ }^{1}$ Dr. Öğr. Üyesi, Niğde Ömer Halisdemir Üniversitesi, IïBF, Kamu Yönetimi Bölümü, ascoban@gmail.com
} 
sonra siyasal iktidar ve otorite kavramları gözden geçirilecektir. Son olarak özgürlük ve otorite ile ilgili temel sorular değerlendirilecektir. Sonuç olarak, bu iki düşünürün en önemli kavramları olan özgürlük ve otorite hakkında bir değerlendirme yapılacaktır.

\section{Introduction:}

Freedom and authority always go hand in hand with each other in any political theory. Beyond thinking their dichotomy as a zero-sum game, J. Locke and T. Hobbes who are the major figures of classical political thought present sometimes parallel, sometimes divergent ideas about conditions of freedom and nature of authority. The major objective of this article is to delineate the differences and similarities in the thoughts of two classical leading philosophers with respect to two concepts, namely freedom and authority. To that end, firstly a conceptual framework about authority and freedom through which I try to show their very relatedness with some other similar concepts such as, political power, individual liberty, legitimate power, law, despotism, obedience, responsibility, voluntary action, consent, power etc. will be presented. Secondly, the question of how Locke and Hobbes conceptualize liberty, political power and relation between them as well will be tackled with in detail respectively. Lastly, although there is no direct intention to compare these two figures in their conceptualizations, I will briefly mention their similarities and differences on the issue and conclude by making a general assessment on freedom and authority.

\section{Freedom in the Relationship between State and Individual:}

Perhaps the most important problematic of political philosophy is the relation between state and individual, the former represents human's inclination to live together in order or 'sociability of man' as Aristotle posits, latter, on the other hand, represents alleged human nature motivated with freedom or autonomy. According to Robert Paul Wolff (1970), there is not any political system to overcome the antinomy between human's first liability of freedom and state's determining role of authority. To Wolff, the only way to overcome this on the part of individual freedom is anarchy. Hobbes on the other hand suggests just the opposite of this and argues for the absolute authority to control the will of freedom in humans. Here, one can recognize the presupposition of the dichotomy between authority and freedom in both theories (Saraçoğlu, 2002: 87-96). In order to truly analyze this dichotomy it would be useful to continue with concepts of freedom and authority in some detail. 
In general freedom means ability to act whatever individual wills, liberty on the other hand means the absence of restraint. To Barry (1995) "a person is free to the extent that her actions and choices are not impeded by the actions of others. Although most liberal thinkers maintain that it is the deliberate actions of others that inhibit the liberty of the individual this is not necessarily so" (Barry, 1995: 206). According to Raphael (1990), the meaning of freedom which is relevant for social and political discussion is to carry out what one has chosen to do. As different from freedom of choice social freedom could also mean "absence of restrain on doing what on chooses or what one would choose to do if one knew that one could" (Raphael, 1990: 56). When one thinks liberty as the absence of external restraint, liberty should be related to power; on the other hand, if we understand liberty as voluntary or uncoerced action then it should relate to responsibility (Barry, 1995: 207). In the first case, "it is true that the purely formal account of liberty as the absence of constraint gives us no clue as to how effectively people may be able to use their liberties, but the conceptual identification of freedom and power leads to us the bizarre conclusion that the perfectly free agents is someone of unlimited power" (Barry, 1995: 211). In the second case one must discuss that to what extent we are free to act as we want because we sometimes want or choose to do something as it comes true or morally right. Then, freedom can be defined as connected with one's duty as idealists did. Idealists in general, maintain that "true freedom is doing of one's duty". According to them we are not unfree in doing our duty. People who have higher self or fulfilled himself do not make feel unfree when doing his duty.

According to Raphael, in this understanding, the problem is that idealists are confusing the freedom of choice with freedom of inner harmony" or with "freedom of conscience" (Rapheal, 1990: 60). Considering the example of a slave who is contented with his lot and genuinely does not want any different status, if freedom is defined as the absence of restraint or satisfying present desires it follows that the contented slave is not unfree. For this reason, Raphael points out that, the concept of freedom is restricted neither with freedom of choice or equal to our wills and desires nor with the absence of restraint. He is to some extent in favour to combine these two understanding and stresses upon the importance of "freedom to give effect to one's choice" (Raphael, 1990: 62-63). This stand indicates that in order to truly analyse concept of liberty, we are better to go further 'two concepts of liberty' which is first introduced by Isaiah Berlin's 
(1958). That means neither the conception of 'negative liberty' which basically refers to the 'absence of restraint' nor the conception of 'positive liberty' which connotes to freedom to act according to one's own purpose or will. In other words, one can argue that when freedom connotes much more moral and social meanings, liberty on the other hand gains its meaning more in political and judicial manners. Hobbes similarly uses the word freedom in more moral and in social meanings and uses the word liberty as more connected with the conception of sovereignty in Leviathan.

By liberty, is understood, according to the proper signification of the word, the absence of external impediments, which impediments may oft take away part of a man's power to do what he would, but cannot hinder him from using the power left him according as his judgement and reason shall dictate to him (Hobbes, [1651] 1894 :66)

Hobbes did not make any distinction between liberty and freedom. Instead he dignifies the rationality of man:

Liberty, or "freedom," signifieth, properly, the absence of opposition; by opposition, I mean external impediments of motion; and may be applied no less to irrational and inanimate creatures than to rational (Hobbes, [1651] $1894: 100)$.

In another place freedom is understood as "not to be subject to laws" (Hobbes, [1651] 1894:149), and this is only in state of nature where there is no limit for the sake of selfpreservation.

\section{The Relationship between Law and Freedom:}

There are two ways of thinking in this relationship: Philosophical approach and political approach. These two concepts at first sight seem contradictory to each other and it is disputable and never-ending discussion whether humankind is inclined to be governed or seek unlimited freedom. When society is concerned Aristotle argued that some people are born to be obey and other are to rule: 
It is also from natural causes that some beings command, and others obey, that each may obtain their mutual safety; for a being who is endowed with a mind capable of reflection and forethought is by Nature the Superior and Governor, whereas he whose excellence is merely corporeal is formed to be a Slave... (Ellis, 1778: 3).

The classical theories of liberty assert that the existence of law implies the absence of freedom. However, people do freely choose to break the law. In a parallel manner "Hobbes maintained that freedom and threat were not antithetical that, someone motivated by fear was nevertheless free" (Barry, 1995: 207). In fact, this is one of the most extreme "absence of constraint" accounts of liberty "since it puts virtually no conditions, except physical ones, on the exercise of freedom" (Barry, 1995: 212). Accordingly, Bentham believed that law and liberty is inconsistent, and every law violates the freedom. On the other hand, Raphael (1990) argues that, law requires doing things and this refrain us from certain actions. The restrictions upon liberty imposed by the law may be intended to protect liberty of others. For either of these reasons the restrictions of law may be desirable indeed essential. And a democratic society considers the high value of individual freedom and state authority is limited deliberately (Rapheal, 1990: 64). It is clear that "for the benefits of liberty to be enjoyed there must be a legal framework within which action can take place" (Barry, 1995: 212). John Locke, unlike to other liberal thinkers, maintained that law and liberty are not inconsistent with each other. According to Locke "the end of the law is, not to abolish or restrain, but to preserve and enlarge freedom" (Barry, 1995: 213). In this manner, with Locke's own words:

Adam's children being not presently as soon as born under this law of reason were not presently free. For law, in its true notion, is not so much the limitation as the direction of a free and intelligent agent to his proper interest and prescribes no farther than is for the general good of those under that law (Locke, 1823: 128).

For Hobbes, authority is necessary because unlimited freedom in state of nature will bring the end of human life which is "solitary, poor, nasty, brutish and short" (Hobbes, [1651] 1894:64). 


\section{Authority and Political Power:}

Authority is the term which is mostly used together with the concepts of "power" and "political power". Some scholars argue that authority means legitimate power whose judgements and decisions are accepted without any question and subjects are in a complete trust and obedience to authorized person or people. On the other hand, it is also argued for some that the concept of authority has a very wide meaning as it may refer to 'influence' or 'power' of somebody over others and not necessarily refer to power of a government. For this reason, it is better not to use authority and legitimate power interchangeably. Mostly, authority means executing a will without applying any force and coercion in this manner it is pre-accepted that when authority has resort to force then it could be considered as legitimate". (Kapani, 2003: 52-53). Clarifying the meaning of political power, Barry signifies the importance of political power as a relation. According to Barry (1995) political power can not be characterized as a free exchange relation between people yet it requires a relation of conflict. For example, in a pure economic sphere an exchange relation is a voluntary act between two or more people, however in a power relationship somebody obeys to rules of another through fear of sanctions and threats. Although this kind of relationship could be considered as an exchange relation from the point of political theorist "it is the essence of power relationships that they involve the diminution of liberty, but this is not normally a characteristic of exchange. To the extent that exchange takes place within the context of authoritative rules, freedom and authority may not be incompatible. Although this form of authority may be compatible with liberty, other types of authority relationships may not be" (Barry, 1995: 92). In this manner, the distinction between authority (political power) and power (physical power) is significant. Hobbes realized this distinction even if he is one of the philosophers of 'might is right' doctrine with his Leviathan. Hobbes' description of authority is not "the mere existence of coercion but the fact that people are sufficiently motivated, albeit through fear, to obey voluntarily" (Barry, 1995: 93). It is the same point Kapani underlines that, political power is not merely about the threat of force and coercion, but it includes the element of consent (Kapani, 2003: 54). On the other hand, Barry underlines one important point that distinguishes Hobbes' understanding of authority and modern political analysis on authority. In Hobbes, the source of authority and legitimacy of the sovereign are directly connected with the consent of the people. Differently, in modern political theory the way in which the obedience is secured depends on the law. That means, "the exercise of authority is a product of rules" (Barry, 1995: 94). According to this, it can be said that, the first 
bearer of this idea was Locke. Subsequently, "it may be essential for the exercise of liberty that rules guaranteeing some predictability should be enforced, however, their existence -as some argue like Wolff- implies at least the possibility that freedom will be threatened" (Barry, 1995: 97). Consequently, "most political theorists recognize that individual liberty and state authority conflict with each other, and that a balance has to be struck between them and the values they represent". Roughly speaking, some like Hobbes are prepared to say that liberty must be severely limited to make way for benefits of State authority. Others like Locke think that "state authority should be markedly limited so as to leave as much room as possible for liberty". It is not possible for complete liberty and complete authority to exist together. "There is, however, a line of thought which tries to say that the two do go together and that omnicompetence for the State is the only way to secure full and genuine freedom" (Raphael, 1990: 77-78). True enough, we will see the trace of this argument in the ideas of Locke as well.

\section{Freedom and Authority in J. Locke:}

J. Locke (1632-1704) is mostly known as the founding father of liberalism proposed his ideas about freedom as oppose to Robert Filmer who was a defender of unlimited state authority. In the second treaty one can see the major themes of Locke's political philosophy which forms the basis of his liberal doctrine and theory of law. Locke was in favour of a legitimate and unlimited political power. For him, political power was a natural property of individuals.

Political power, then, I take to be a right of making laws, with penalties of death, and consequently all less penalties for the regulating and preserving of property, and of employing the force of the community in the execution of such laws, and in the defence of the commonwealth from foreign injury, and all this only for the public good (Locke, 1823: 106).

In addition to this, he defended a constitutional and a parliamentary state. Arguably, philosophy of Locke was a response to the central themes of the $17^{\text {th }}$ century political environment in Europe and particularly in England and was a strong criticism against the theories of absolute monarchy held mainly by T. Hobbes, R. Filmer and J. Bodin (Ağaoğulları, 2005: 163, Tully, 1993: 13). At that time, civil and religious wars brought the problem of "political power" and/or "sovereignty" into issue. There were all struggles for political power and the major question was the juridical representation of politics particularly in the context of the struggles between 
King, Parliament and people in England. "The practices of governing conduct by universal rights and duties, law and sovereignty had become so central by the $17^{\text {th }}$ century that Locke could write that moral, political, theological and legal thought and action rest on the indubitable assumption (and practice) that man is an animal 'subject to law' (Tully, 1993: 13).

For Locke, the source of legitimate authority and the responsibilities of citizens are natural laws which he derives from the universal natural law. Natural law secures the peace, freedom, and equality in state of nature. Natural law, which is no other than the reason, teaches people that they should not harm in the freedom, life and property of other people as they are all equal and free by nature (Ağaoğulları, 2005: 165). Furthermore, as a state of equality or absence of any supreme political will, in state of nature anybody has right to judge and punish the other. As a state of freedom, in state of nature there is no freedom to abrogate one's own life and property on the other hand, individuals are free to use their properties as they want. Limits of freedom refer to the responsibilities of individuals towards each other that are determined by the natural law (A ğaoğulları, 2005: 166-167). From the point of natural rights, freedom is not other than the equality of natural rights. "We all have the equal right to freedom from harm and interference by others provided only that our actions stay within the bounds of natural law". We are free to do our duties and pursue our plans and projects (Simmons, 1992: 85).

In Locke the goal of the social contract, which also refers to the need for constitutional political authority, is to protect property. Property has two meaning: property in a strict manner and property in an extended manner, comprising, life, liberty and estate. In both meaning property is a natural right and mostly Locke takes both meaning into account in his theory. As we have seen, in Locke, liberty finds a place under the second meaning of conception of property. Liberty is important for Locke that, if there is no liberty or if liberty is restricted then the property will be at stake. Since authority must protect property, it also has to protect liberty. Precedence of natural rights also gives subjects the right to resist against the authority in case it violates the right to live and freedom (Ağaoğulları, 2005: 172-175).

Locke distinguishes natural liberty from civil liberty. This distinction is important to understand the formation of the concept of 'civil society' or 'public sphere' in which citizens actively judge the policies of government in the light of public good (Tully, 1993: 281). According to him, 
The natural liberty of man is to be free from any superior power on earth, and not to be under the will or legislative authority of man, but to have only the law of Nature for his rule. The liberty of man in society is to be under no other legislative power but that established by consent in the commonwealth, nor under the dominion of any will, or restraint of any law, but what that legislative shall enact according to the trust put in it (Locke, 1823: 114).

In addition to this, Locke uses the terms 'freedom' and 'liberty' in two senses: "as a 'state' or 'condition' of freedom and as an 'ability' or 'power' the exercise of which is the purpose or point of that condition or state" (Tully, 1993: 291). Having emphasized, for the first sense, being not under the will of another man but under the natural law is necessary opposing argument of Locke against Filmer since he believed that natural freedom conduces anarchy. In the second sense 'reason' is the major element in creating the conditions of liberty in that, "freedom of man and liberty of acting according to his own will, is grounded on his having reason" (Tully, 1993: 292).

The relationship between will, power and freedom is also a salient point in Locke' understanding of liberty. As to Locke, man is not free when he cannot do the action he wills: But this can be a voluntary action as it is necessary. So, describing freedom should include will plus power to do or/and not to do the action willed: freedom of choice and action (Tully, 1993: 295). Remembering the meaning of will as identical to desire in Hobbes and Filmer, Locke, Tully underlines whereas the voluntarist notion of freedom adopted by Hobbes and Filmer and parallel with Isaiah Berlin's negative conception of freedom, 'freedom from', Locke's conception of freedom runs parallel to positive freedom; that is 'freedom to'. However, Berlin was wrong in suggestion that, according to Tully, philosophical foundation of the liberal freedom refers to the concept of negative freedom even though Berlin confesses that he has difficulties in classifying Locke (Tully, 1993: 298). On the other hand, Simmons (1992) points out the conception of the composite right which Locke calls as 'the right of freedom to his person'. "It includes the right to do our duty, the right to pursue our nonobligatory ends, and the powers to make special rights that are important to our freedom of action" (Simmons, 1992: 85). This element of obligation signifies that conception of freedom in Locke, can not be considered as merely a positive one. 
Locke sets several reasons to justify the transition from state of nature to civil and political society. As I have already mentioned, in state of nature, there is a natural freedom and equality among people, but there are irrational peoples who violates the natural rights and impartially judge other people. In order to abstain from these arbitrary actions of individuals the abstention from an all-powerful ruler is very rational for Locke. In other words, "Locke believed that natural law required everyone to be subject to the law and equal before it. An all-powerful sovereign would not be equal to others under the law, as the sovereign would be the judge of his case. Locke concluded, therefore that such a government would violate natural law and the original purpose of creating civil government" (Godwin and Wahlke, 1997: 49). Another reason for a need a limited government is three deficiencies in state of nature; these are, absence of a common law constituted through common consent; absence of an independent judger who stick to that law and will solve the conflicts between individuals and absence of an executive power who will give effect the punishments given by the independent judger (Ağaoğulları, 2005: 190). "Political society is constituted by the agreement of each person to become a member of a community or 'Body Politick' in which the 'Majority' have a right to act and conclude the rest. The majority decide on a constitutional form for the community (monarchy, democracy etc.) and place political power in the hands of the 'legislative' or law-making body which places the power to enforce laws in the hands of the executive" (Tully, 1993: 316). The reason for showing consent to pass to civil society and then to political society is not only derived from the rationality of man but also from his natural duties "not to harm another in his life, health, liberty or possessions” or positively 'preserve himself' and 'preserve others' (Tully, 1993: 299).

In the second treaty Locke gives the examples on a husband and a wife. Their bond turn into an agreement. For him, marriages are examples of political or civil societies as there is mutual support and assistance according to marriage contract (Locke, 1823: 139-140). Thus, the ideal government of Locke has duties as well as responsibilities as a corporate body such that government should act according to common good. To put it differently, political authority is expected to “(1) protect citizens' natural rights of life, liberty and property; (2) punish people who violate the rights of others; (3) adjudicate disputes when occur" (Godwin and Wahlke, 1997: 50). Accordingly, Locke declares: 
...no political society can be, nor subsist, without having in itself the power to preserve the property, and in order thereunto punish the offences of all those of that society, there, and there only, is political society where every one of the members hath quitted this natural power, resigned it up into the hands of the community in all cases that exclude him not from appealing for protection to the law established by it (Locke, 1823: 141).

If rulers destroy the natural rights of the citizens or do not use power on behalf of public interest and behaving unjust and illegitimate, then subjects could legitimately overthrow their government. After the dissolution of government, people who gain full constituent authority have the capacity to re-establish or select a new political community, governed by majority rule (Godwin and Wahlke, 1997: 50; Ağaoğulları, 2005: 196; Tully, 1993: 40-41). At this level, it is important to realize that, what guarantees the liberty and the prevention of arbitrary power is natural rights that individuals have in state of nature.

Not surprisingly, Locke relates civil law and liberty in a positive way. It is not surprising because when men enter political society, they give the exercise of their powers to political society. "Government is thereby under natural law in the same way man is in the state of nature" (Tully, 1993: 299). As "law is constitutive of freedom, perfecting or completing it as its final cause" if there is no law then there is no freedom, too (Tully, 1993: 297). In contrast to Hobbes and Filmer, in Locke law is not a limitation on the part of freedom. However, it is the same with realization of civil liberties. According to Tully, from all these arguments one can conclude that Locke's theory is an individualistic one of popular sovereignty" (Tully, 19936: 299). On the other hand, some like Seliger (1969) argue that in Locke "neither freedom under government nor freedom of nature or natural freedoms are unlimited". Moreover, "law maximizes freedom because by imposing limitations upon men it liberates them 'from restraint and violent from others' which cannot be, where there is no law". Thus, Locke's conception "implies thus the empirical definition of liberty as the absence of constraint by others. If we call this 'negative' liberty and 'positive' liberty consists in being self-directed inasmuch as one is moved by reason, the two liberties condition each other in Locke." Because "Locke did not mean that law does not constrain, but that without constraint no amount of freedom is assured (Seliger, 1969: 167 168). There are also some scholars holding the idea that conception of liberty in Locke correspondences to 'power of contingency'. That means, Locke insists on that freedom is a 
power or faculty of the agent, however one should consider the fact that a "mere absence of external impediments can constitute such a power" (Rapaczynski, 1987: 132). These discussions give us a clue that it would be mistaken to consider Locke either as a defender of positive freedom, or as that of negative one and keep in mind that one cannot perceive negative and positive conceptions of freedom as mutually exclusive categories.

Letter on Toleration (1689) within which Locke declares his ideas about freedom of expression is the most known work of him on philosophy of freedom. There, Locke maintains that state cannot intervene in thoughts of individuals as well as cannot retain individuals in expressing their thoughts. Locke declares that:

We judge no man in meats, or drinks, or habits, or days, or any other outward observances, but leave everyone to his freedom in the use of those outward things which he thinks can most contribute to build up the inward man in righteousness, holiness, and the true love of God and his neighbour in Christ Jesus (Locke, [1689], 2013: 136).

Furthermore, state should not be coercive in freedom of conscience, faith and religion because the major objective of state is to protect property (Ağaoğulları, 2005: 224). Also, he developed his idea of 'glorious revolution' which is parallel to his understanding of freedom and asserted that the mere guarantee of freedom is rebellions that emerge and progress spontaneously (Ăgaoğulları, 2005: 224).

Overall, for Locke, "people are naturally self-governing, because they are capable of exercising political power themselves; naturally free, because they are not naturally subject to the will of another" (Tully, 1993: 159). Furthermore, Locke's conceptions of trust, consent and revolution indicates according to Tully that, "his account of civil liberty is similar to republican or civic humanist theories in which political liberty consists of participation in a self-governing commonwealth" (Tully, 1993: 301). Finally, one can truly argue that in Locke, the idea of freedom and authority always intertwines with each other. 


\section{Freedom and Authority in T. Hobbes:}

Thomas Hobbes (1588-1679) who is mostly known with his authoritarianism and the conception of absolute sovereignty is a $17^{\text {th }}$ century English philosopher. The originality of his thoughts comes from his discarding of divine right of kings and search on a secular source of sovereignty with the help of is theory of natural law and the idea of social contract. He pursued this aim in his famous work Leviathan (1651). In this section, after mentioning his conception of social contract, sovereignty and properties of the sovereign, I will proceed with his conception of liberty.

As oppose to Locke, in Hobbes, state of nature is a state of war, fear and trick. Everybody is equally imposed to inappropriate conditions of state of nature. There is a state of natural equality. Everybody follows his own passion; compete for limited resources, prone to act wildly. That is state of nature is a state within which "man is wolf to man". Moreover, as it is not a moral society, there is neither good nor evil, neither justice nor injustice in state of nature. All moral values come out after Leviathan which is the result of mechanical process, final point that the movements of people have reached (Zabc1, 2004: 178; Russell, 1996: 302). Also, people are not social by nature instead they are motivated to enter into a civil society due to their fear for their lives since the basic drive of man is self-preservation. That is, "Hobbes claimed that, it was not natural sociability but calculations of how best to provide for self-preservation which led people to enter commonwealths, and that there were no reliable moral institutions expect those deducible from the principle of self-preservation" (Sommerville, 1992: 39). Hobbes explains the laws of nature and character of the social contract as the following:

...the first and fundamental law of nature, which is, to seek peace, and follow it. The Second, the sum of the Right of nature, which is by all means we can, to defend ourselves. From this Fundamental Law of Nature, by which men are commanded to endeavour Peace, is derived this second Law; That a man be willing, when others are so too, as far-forth, as for Peace, and defence of himself he shall think it necessary, to lay down this right to all things, and be contented with so much liberty against other men, as he would allow other men against himself (Hobbes, [1651] 1894: 66). 
Basically, the conception of freedom is too, in Hobbes, understood as related to the conception of 'natural right' which is not other than the people's freedom of self-preservation including preservation of his life, his nature and his will (Zabc1, 2004: 197).

Indeed, Leviathan is an artificial body constitution of which begins with the consent of individuals in state of nature. With respect to this, Hobbes argued that "free and equal individuals in the state of nature will perceive that their situation is one of radical insecurity and will therefore be led to agree with each other to abandon the right of nature and erect a common power over themselves" (Sommerville, 1992: 52). Parallel to this, in the second part of Leviathan Hobbes states that in order to get rid of all the clashes in state of nature, people gather into communities each having central authorities. In this way, people get agree on an authority of a sovereign who will end up the universal war situation (Russell, 1996: 302).

Social contract binds only the people who will become citizen as the contract is between individuals not between the sovereign and individuals. "This contract bound them to renounce their rights to kill and steal and gave the state the power to enforce this contract" (Godwin and Wahlke, 1997: 46). Leviathan is thereby an impartial supreme authority as the guarantor of this social contract. There is no possibility of war after Leviathan because there is no more insecurity and severe competition between people and the final aim of the sovereign it to secure the peace. In addition of this, will of the sovereign is equal to will of people. Leviathan is also the mere condition for the implementation of social contract because for Hobbes, when there is no obligatory power not ever contract could be implemented (Zabc1, 2004: 213-215). True enough; the idea of contract is a myth which necessitates people's obedience to an authority at the expense of their freedoms (Russell, 1996: 302).

On the other hand, Hobbes was very challenging considering his time when he leans the sovereignty on an artificial body which is resulted from its mechanical materialist philosophy. It can be argued that the reason for describing Hobbes as a modern philosopher depends mainly on his mechanistic account of political theory and his idea of social contract which hinges upon the artificial compromise between rational individuals. In other words, it is a rational action to choose to obey a sovereign because, 
For by this authority, given him by every particular man in the commonwealth, he hath the use of so much power and strength conferred on him, that by terror thereof, he is enabled to perform the wills of them all, to peace at home, and mutual aid against their enemies abroad (Hobbes, [1651] 1894: 84).

According to this, the source of authority emanates not from the will of God but from the mechanical calculations of rational men directed to the formation of an authority as a part of a mechanical process apart from any agent. Although Hobbes' attempt could be considered as a replacement of God's will with the will of Leviathan as an all-powerful authority, the secular trend which Hobbes adopted is worth enough to classify him as a modern thinker. It is important again to point out that for Hobbes, "all authority at least all authority that men may have over other men, derives its legitimacy from man-made arrangements and it may also imply that the will of the people replaces the will of God in that, in principle at least, it no longer knows any legitimate limits" (Rapaczynski, 1987: 25).

True, people lose all their rights and freedoms once they agree upon a sovereign and they have no right to rebel against the sovereign. Leviathan is similar to an unlimited, supreme authority, has unlimited competence having the right to censor over thought, having the all property as well as all laws about property is under the control of the sovereign since property is protected and distributed by the sovereign (Russell, 1996: 303; Zabc1, 2004: 240). This is because, as oppose to Locke, for Hobbes, property is not a natural right of people and although people have property, they cannot use it against the will of the sovereign and sovereign can take property without the consent of the individuals. That is “it is the sovereign's will alone which defines whether something is a person's property, so no one holds rights of property against the sovereign (Sommerville, 1992: 89). Nevertheless, all the power and will of the sovereign come from the people's own will instead of the divine right of the sovereign and all the power of sovereign has to be used for the peace, preservation and even to protect the freedom of individuals (Zabc1, 2004: 230). This paradoxical situation could be explained through the conception of human nature Hobbes adopted. Because Hobbes' envisagement of human nature necessitates such an authority. "He argued that coercion is necessary because people are prone 
to act irrationally ${ }^{2}$. Reason, Hobbes says, demonstrates that it is expedient for us to agree together to set up an authority which will resolve conflicts between us. But passion inclines us to break our agreements unless they are enforced by coercive means" (Sommerville, 1992: 41). Furthermore, according to Hadrian Savaria and as to Jean Bodin sovereignty is essential to human society as without it, social relations cannot last long since "people would be led into conflict with one another by love of liberty". Hobbes, in a parallel manner, agrees that "it is natural love of liberty, pride and other passions which make coercive government necessary" (Sommerville, 1992: 83).

In Shochet' (1990) view, 'the chief conceptual problem for Leviathan was to devise (or discover) a means of obliging people -specifically man- to obey the absolute political authority that could protect them from their own worst inclinations and behaviours" (Shochet, 1990: 57). In Hobbes, insecure and unstable situation as a reflection of brute strength in state of nature "provided the only route to stable and secure existence. But the imposition of 'authority' and the establishment of social ties by means of strength and might would destroy natural 'freedom' and equality" (Shochet, 1990: 59). In other words, freedom and equality is legitimately overcome by strength, it is an intentional surrender of them by rational man and it is the consent of individuals which makes the authority legitimate. This may seem to be paradoxical considering person's own sovereignty over his actions as part of his natural right, yet one can argue that Hobbes could overcome this paradox through his understanding of human nature which is rational enough to obey and give consent (Shochet, 1990: 60-61).

Furthermore, in Hobbes, there are two forms of sovereignty concerning the establishment of it. The first one is 'sovereignty by institution' and the second one is 'sovereignty by acquisition'. The first refers what I have mentioned so far and related with the theory of authorization, however the second one is related to promise on the political obligation and/or refers to the covenant on the promise to obedience to a common authority. To put it clearly,

\footnotetext{
${ }^{2}$ In Hobbes' philosophical project, rationality can only be found as a potential in human nature in order to move to political society. Rationality does not belong to individuals by nature instead it is a part of mechanical process (my point)
} 
A Commonwealth "by acquisition," is that, where the sovereign power is acquired by force ; and it is; acquired by force when men singly, or many together by plurality of voices, for fear of death, or bonds do authorize all the actions of that man, or assembly, that hath their lives and liberty in his power. And this kind of dominion, or sovereignty, different from sovereignty by institution only in this, that men who choose their sovereign do it for fear of one another, and not of him whom they institute: but in this case, they subject themselves to him they are afraid of (Hobbes, [1651] 1894: 95).

According to Hampsher-Monk (1992), the first set up of sovereignty depends on the idea of authorization and "the idea of authorization derives from medieval developments in the Roman Law theory of corporations, giving rise to the useful notion of an artificial or 'legal' personality which could bear rights and own property on behalf of a collectivity" (HampsherMonk, 1992: 40). 'Sovereignty by acquisition' on the other hand, is closer to the idea of social contract; it is a personal Feudal Contract of fealty. This second one is also much more related to the ensured fidelity to sovereign in case of the threat from outside of the country in so far as their mere natural right, self-preservation is protected. Because "political legitimacy depends not on how a government came to power but only on whether it can effectively protect those who have consented to obey it, political obligation ends when protection ceases" (Lloyd, $2006)^{3}$.

Shochet (1990) pays attention that Hobbes' conception of human nature depends on an intentionalist approach rather than the classical liberal account of political obligation. This is because "political obligation is a product of personal will, that it is consent or agreement that actually ties one to the sovereign ruler" (Shochet, 1990: 57). This intentionalist approach is also clear from his account on the origin of sovereign power and civil society which are derived from 'institution' and 'acquisition'. Shochet argues that 'institution' 'makes possible the conceptions of authorization and representation that are essential to the organic relationship between sovereign and subjects... 'Acquisition' on the other hand provides a context in which the individual's sole, preserved right against the sovereign, the right of self defence, can be

\footnotetext{
${ }^{3}$ Lloyd, Sharon A., "Hobbes's Moral and Political Philosophy", The Stanford Encyclopedia of Philosophy (Fall 2006 Edition), Edward N. Zalta (ed.), URL=<http://plato.stanford.edu/archives/fall2006/entries/hobbes-moral/>.
} 
understood and from which the dependence of obligation upon protection can be derived" (Shochet, 1990: 58). "These are equally legitimate ways of establishing sovereignty, according to Hobbes, and their underlying motivation is the same -namely fear- whether of one's fellows or of a conqueror" (Lloyd, 2006). It would be sound to argue that, conceiving sovereignty as an acquisition implies not only the modern face of Hobbes but also the open way of this theory towards people's sovereignty remembering the democratic character of the precise moment of the social contract and his stressing upon the absolutism as a nature of sovereignty rather than the absolute monarchy as a specific form of state (Zabc1, 2004: 230).

To proceed with the rights and characteristics of the sovereign, "the rights of the sovereign are as extensive as the right of nature, and effectively unlimited" (Hampsher-Monk, 1992: 45). Sovereign has the natural law ensuring his absolute freedom just similar in the case of individual in state of nature. Furthermore, there is not any other power that restricts the power of the sovereign in contrast the case of individual in state of nature. The power of sovereign is unlimited, he is not bound to laws which he made and cannot accept any power over him. Indeed, this is the sole condition for peace (Zabc1, 2004: 230-234). On the other hand, since natural law commands the obedience to social laws, laws which are made by the sovereign cannot be oppose to natural law which represents the justice and sociability (Zabc1, 2004: 236). In line with this vision, “it is the sovereign's responsibility, for which he is not he is not answerable to his subjects, to judge what is necessary for peace and for warfare, what doctrines are to be taught, what are the rues or laws of property, to arbitrate on all quarrels within the state, to make war and levy the troops and funds necessary to do so, to choose his own ministers and to award honours" (Hampsher-Monk, 1992: 45). That is to argue that; sovereign does not have any responsibility to his subjects in a moral sense but to the natural law. Because, "what gives the commonwealth its unity is sovereign, who has been authorised by each individual to bear his person. Every individual authorises all the actions of the sovereign" (Sommerville, 1992: 60). Even "if the sovereign granted his subjects any liberty which was incompatible with sovereignty, they had a duty to ignore the rant and continue to obey his commands" (Sommerville, 1992: 82).

Also, it is useful to restate that; absolute sovereign does not have to be the monarch but can be a council as well. This indicates that, as I have just emphasized above, for Hobbes, the matter 
is the continuity of the sovereignty and peace rather than the absolute monarchy as a political form of government. On the other hand, this also indicates the opposite of the democratic structure of state raised at the same moment of social contract. That is, "if the representer is one man, then the form of government is monarchy, and therefore it is not necessary that the original form of government in every commonwealth be democratic" (ibid). Furthermore, common good is determined based on the reason of the sovereign and "there is a closer identity between individual and the public good" (Zabc1, 2004: 237; Hampsher-Monk, 1992: 47).

It can be maintained that, civil and religious wars in Hobbes' time very much influenced his conceptions of sovereignty and sovereign. True enough, these conceptions "marks the emergence of the modern idea of the concept as the defining quality of political bodies". To put it in a more comprehensive manner, "Hobbes himself moves easily from talking about the sovereign as a person or a body, to sovereignty as the particular collections of power exercised by such a person, and so to sovereignty as those powers constitutive of the authority needed to maintain a state in being" (Hampsher-Monk, 1992: 47).

As regards liberty, state of nature in Hobbes, is the state of absolute freedom. However, in state of nature there is no individuality at all, as it emerges after the social contract and man can be considered as individual after he has property. Absolute freedom in state of nature is a paradox in that since every individual has absolute freedom and equality then one cannot speak about freedom at all (Zabc1, 2004: 262). In Chapter 14 of Leviathan, Hobbes defines liberty as "the absence of external impediments". In Chapter 21 he defines it as the "absence of hindrance or doing whatever man has the will, wit and ability to do". However, Hobbes states that the second definition is a generally accepted meaning of liberty in England and he does not espouse it at all instead he insists on the qualification 'external'. "Thus, liberty is consistent with fear. A man robbed at gunpoint would be free according to Hobbes' doctrine. Not the robber (external) but the fear (internal) constitutes the impediment. If the victim hands over his wallet he is acting voluntarily; and for Hobbes, a voluntary action and a free action are one and the same" (Pennock, 1960: 98). Add the point that, voluntary action does not mean 'freely chosen' or 'freely willed' in Hobbes since our actions are determined by the mechanical movements of nature. In other words, voluntary actions of individuals are result of the serials of necessary mechanical movements of them (Zabc1, 2004: 261). 
After Leviathan, liberty of citizens is equalized with liberty of the sovereign. Individuals have no liberty apart from the liberty of state. There is only one way for liberty: a passive obedience of subjects to state and laws of the sovereign. In this respect, liberty cannot be thought apart from the necessity, the necessity to obey rules which protect and preserve the peace. Likewise, as far as the states are free, subjects are, too (Zabc1, 2004: 262-263; Hampsher-Monk, 1992: 49). Moreover, according to Hobbes, since law is equal with the will of the sovereign, liberty is meant silence of the law. In the same way, "someone has a liberty to do something is to assert that the sovereign has not in fact forbidden the action in question" (Sommerville, 1992: 95).

Hobbes' conception of self-assumed political obligation is very connected with how he justifies his conception of human liberty. For him, "self-assumed obligations are in general more legitimate than those that are imposed to someone against her or his will. That is to say that the starting point of a theory of obligation is human liberty, for an individual can only be bound to do that which before becoming so obliges he or she was free not to do" (Wolin, 1990: 69). On the other hand, it is clear that there is no any place for freedom such that even if obligation is self-assumed and result of voluntary acts, freedom as a course of action is impossible in such a context (Rapaczynski, 1987: 97).

To state again, "fear and liberty are consistent. Because Hobbes depicted man as timid and fearful by nature, it appears in keeping with that Hobbesian man should submit himself to absolute power" in spite of the fact that for the establishment of political power, power of the man is needed (Wolin, 1990: 28). Properly speaking, "for Hobbes liberty is applicable only agents considered as bodies and their actions considered as movements, and not to properties of agents (such as their wills), or their internal motions (such as motives and reasoning)...Our wills are part of a universal causality. Our liberty is in a sense, only a manner of speaking about particular cause of movement" (Hampsher-Monk, 1992: 50). To put in other words, "liberty and necessity are consistent. Liberty is not a unique property of man, and it does not signify freedom to choose but the absence of external impediments that block his power" (Wolin, 1990: 28). However, the result of this case is that "we cannot distinguish between free and unfree acts on the basis of some external factor impinging on the will that gives rise to them" (HampsherMonk, 1992: 50). 
An explanation for his perception of freedom, by Hobbes, related to obligation, fear and necessity and could be found his priority and search on security and order in the face of terrifying disturbance due to civil war in England. In fact, "Hobbes was a straightforward choice between order and liberty: Order comes first, he asserted, and the state must limit liberty" (Godwin and Wahlke, 1997: 47).

There is also another conception of liberty in Hobbes: Liberty of natural individual. This liberty is not about civil life or public sphere. It is a natural within which there are some natural rights. In fact, the right to live comprises all other natural rights. This liberty means the right to protect his life or his security referring to negative condition of liberty like the definition of liberty in state of nature. Interesting enough, liberty of natural individual opens the way for a positive sense of liberty at the same time. In this respect, "Hobbes argues that the Right of Nature is "the liberty each man have, to use his own power, as he will himself, for the preservation of his own nature; that is to say, of his own life and consequently of doing anything which, in his own judgement and reason" (McNeilly, 1968:169; Pennock, 1960:102). This definition, to McNeilly, is the manifestation of the distinction between right and law; the former consists in liberty, but the latter contains obligation. And liberty cannot be consistent with obligation for Hobbes (McNeilly, 1968:170). If obligations and civil law limit freedom then as Hobbes stated in Leviathan 141, "liberty comprises the area in which a person is not prevented by obligations or external impediments from doing whatever he has the will, wit and ability to do" (Pennock, 1960:101). At the same time however, liberty as a right does not contain power since right and power are significantly different. Instead liberty as a natural right was transferred to the sovereign according to the law of nature. Thus, "clearly it is not the power but the right (liberty) to exercise the power that can be renounced or transferred, and this by accepting an obligation, an obligation to restrain the exercise of power" (Pennock, 1960:102).

This conception of liberty in Hobbes' theory opens the discussion of whether Hobbes is liberal. Because of this emphasis Hobbes seems to be giving priority to the natural individual rights instead of general will or common good (Zabc1, 2004: 267). Hobbes underlines: "If the sovereign command a man, though justly condemned, to kill, wound, or maim himself; or not to resist these that assault him; or to abstain from the use of food, air, medicine, or any other 
things without which he cannot live; yet hath (has) that man the liberty to disobey" (Hobbes, [1651] 1894: 103). This argument brings about the right of resistance on the part of individuals when the sovereign does not protect their natural right to live. In this case, although social contract becomes invalid since the sovereign has unlimited and supreme power and can kill the individuals if it is necessary for social peace it does not change the fact that people have right to resist against the sovereign (Zabc1, 2004: 267-268). In a similar vein, Hampsher-Monk (1992) argues that "within the state the greatest liberty of the subject depends on the silence of the law, for what is not forbidden by law may legally be done: indeed a subject may sue a sovereign at law within a purely legal framework. Nevertheless, it is always open to the sovereign to demand something simply in virtue of his mere power" and he can punish the resistance of the individual with death. "Ultimately, the right of capital punishment exercised by the sovereign over the individual is no more than the last vestige of the right of nature, and the relationship between the sovereign and a condemned man is essentially that of the state of war" (Hampsher-Monk, 1992: 50-51). For some scholars (i.e. Owen, 2005; Martel, 2016), Hobbes cannot be considered as a representative of liberalism mainly because of his absolutist and authoritarian political obligation understanding and his views on human nature. However, there is little doubt that "the originality of his approach to politics was to consist in rejecting the theological foundations of political philosophy and replacing them with a rooting in natural science" and he never believed that the legitimacy of a government could depend on religious truths (Rapaczynski, 1987: 132). In addition, "his social contract changed the source of political power from divine choice of God to the rational choice of the people". Therefore, it can be truly argued that "his writings set the stage for the development of liberalism" (Godwin and Wahlke, 1997: 47). Levine also agrees with the idea that, Hobbes cannot be considered as liberal in the sense that the power of the sovereign is unrestricted. For him,

Nevertheless, it is fair to depict Hobbes as a forerunner of liberal political thought. If nothing else, the core liberal value, liberty, understood in roughly the way that Hobbes conceived it, as 'the absence of external impediments' was a core value for Hobbes. Hobbes was arguably the first philosopher to conceive liberty this way, and the first to accord it pre-eminent normative force. Hobbes demonstrated that a maximum level of freedom, unrestricted freedom is suboptimal. Where unrestricted freedom exists, individuals' interests as free beings are poorly served. Hobbes central claim, then, was that unrestricted political authority is necessary for 
individuals to attain optimal levels of freedom; that paradoxically, the way to optimize freedom is to restrict by concocting a sovereign whose authority is in principle absolute. Hobbes and liberals part ways on this crucial issue. But they were of one mind on the value of liberty itself. (Levine, 2002: 46).

In Hobbes, we can also talk about liberties in private life. These are liberties about buying and selling property or/and about the sphere of family. For Hobbes, in this private life, people are free act according to what they think as beneficial for themselves since they are rational enough to calculate the economic conditions which are suitable for their individual interests and in this respect they are in competition with others. This indicates the traces of economic liberalism in Hobbes (Zabc1, 2004: 270-271). According to Zabc1 (2004), Hobbes neither could be construed as a liberal nor as a totalitarian. He cannot be a totalitarian as he did not totally bind individual to state since liberty of natural individual is external to state and enables individual's resistance against state. On the other hand, he cannot be considered as a liberal since he did not put individual rights against state (Zabc1, 2004: 269).

\section{Conclusion:}

As we have seen, both Hobbes and Locke present crucial arguments concerning to contention between freedom and authority. One can say that both strive for the legitimacy of their theories on the ground of freedom and authority. Because at that time, it was really hard to justify a secular political authority whether take its roots from the common good or from the natural rights apart from God. As I have mentioned in advance, political power or authority does not mean mere coercion and we can say that both seems to have already realized the importance of 'consent' while forming their theories. On the other hand, their perceptions of consent are very distinct. In Hobbes consent is important for the legitimacy of the absolute sovereign, but in Locke people give their consents to the rule of law rather than an absolute monarch.

To be sure, both Hobbes and Locke are within the natural right/natural law tradition. However, their understandings of natural law are profoundly different. "Hobbes has a naturalistic conception of natural law that masks an egoistic politics of power. Locke's theory rests on a non-naturalistic and moral understanding of natural law" (Canavan, 1979: 971). 
Furthermore, their views on the nature of authority is quite different in the sense that, "For Hobbes, the rules under which individuals ought to live are just those that the sovereign commands, whatever they happen to be". "For Locke, on the other hand, enforcement is necessary mainly to secure rights that pre-exist the establishment of sovereignty" (Levine, 2002: 99). To put in other words, for Hobbes the sovereign state represents 'the public', its interest, will and freedom. It also could defend general or public interest on behalf of the peace, ensure the safety of people. Also, since authority of the sovereign depends on the consent of individuals, it is legitimate. Locke on the other hand, "rejected the notion of a great Leviathan, pre-eminent in all social spheres. "For Locke the authority of state is conceived as an 'instrument' for the defence of life, liberty and estate of its citizens” (Held, 1989: 17-19).

Their understandings of liberty somehow indicate us that the conception of liberty should transcend its negative and positive descriptions because in both we can find the traces of two of the descriptions of freedom. On the other hand, it is true enough, each of them are more dominant in one philosopher. That means Hobbes carries mostly the traces of negative conception of freedom while describing it as the absence of external impediments and could be criticized by Raphael (1990) in that negative conception of freedom should be expressed as the freedom of conscience or freedom of inner harmony since it ignores the internal impediments. On the other hand, the conception of liberty is saliently central -as a natural right- and refers to a more sensible meaning in Locke' theory. That is, liberty is described as the power or the faculty of an agent. Moreover, while in Locke law is for the protection of freedom, in Hobbes law should limit (though unrestricted one) liberty since the matter is liberty of the sovereign as the representative of common will or that is to say that one can reach the liberty of individual from an indirect way. Thus, while in Locke, one can find a more 'individualistic' understanding of freedom in a liberal sense, in Hobbes this individualism only reflects upon the sovereign as sovereign has the liberty. On the other hand, Hobbes can be said to have a margin towards a freedom in a more collective sense. Perhaps the point is Locke begins with the individualism and individual morality and continues with civil and political life, but Hobbes emphasizes on the conceptions of common good or general will as a first step of his political society. This can be because, while in Hobbes the source of sovereignty is people, just as in Locke it is individual rights and freedoms. 
Their understandings of sovereignty are quite different in that, in Hobbes sovereignty is indivisible, unlimited and everlasting however in Locke sovereignty, which can be interrogated by the subjects on the basis of law, is conceptualized on a legislative ground. By this understanding Locke can be said to form the foundation of modern law because in his theory the rule of law implies the ongoing potential limitation of authority on behalf of individual rights and freedoms.

For all, it can be argued that, even though Locke could be seen as the defender of bourgeoisie class and of the interests of property owners, defending the constitutional and limited authority which signifies the critical place of individual freedom, for his time, was very challenging and undoubtedly produced a revolutionary effect in political theory. Especially, Locke's conception of liberalism, limited government, civil liberties, majority decision making, equality under the law and the sanctity of life and property can be said that constituted the basic tenets of western democracies. (Godwin and Wahlke, 1997: 50). According to Shochet (1990) absolutist conception of state adopted by Hobbes cannot be accepted by modern understanding of political power in today's democracies, but “represented what emergent liberal ideology would have to overcome in order to sustain its defence of constitutional politics. The goal was to defend a conventional account of the state that did not collapse into absolutism or ineffectually wither away, leaving its members undefended in either case. It is a goal that still motivates the liberal spirit" (Shochet, 1990: 70).

For Locke both authority and freedom are needed for protecting the right of property, and freedom is assured and sustained only under a legal framework. While Locke conceptualizes the authority as constitutional, Hobbes does it as sovereign or state authority. Notwithstanding the connotations or implications of Hobbes's theory regarding to liberalism, I conclude that, while Hobbes still stands as the representative of those who advocate and believe in the power of nation states and state authority, Locke on the other hand, seems to be as the holder of the understanding which argues for supra-national rights and liberties ultimately reached the conception of universal human rights. All these discussions are also related with the way of grasping liberal ideology as an ideology which is very grounded, substantial and eclectic as well. Both the conceptions of authority and freedom are drawn for liberalism and they can be thought as complementary to each other. 
FSECON ÇOBAN BALCI, A. (2020), "A Review on Freedom and Authority in Theories of John Locke and Thomas Hobbes", Fiscaoeconomia, Vol.4(1), 132-158.

\section{BIBLIOGRAPHY}

Ağaoğulları, M. A. (2005), “Thomas Hobbes: Ölümlü Tanrı” in Ağaoğulları, M. ve Köker, L. (ed.) Kral-Devletten Ulus-Devlete, İmge Yayınları, Ankara

Barry, N. (1995), An Introduction to Modern Political Theory, Macmillan, London

Canavan, F. (1979), John Locke and the Theory of Sovereignty: Mixed Monarchy and the Right of Resistance in Franklin J., 1978; Hobbes and Locke: Power and Consent by Ramon M. Lemos, Book Review, The Journal of Politics, Vol, 41, pp. 970-973.

Ellis, W. (1778), A Treaties on Government, translated from the Greek of Aristotle, Printed for T. PAYNE, at the Mews Gate: London

Godwin, K. and Wahlke, J. (1997), Introduction to Political Science: Reason, Reflection and Analysis, Harcourt Brace College Publishers, TX: Forth Worth

Hampsher-Monk, I. (1992), A History of Modern Political Thought: Major Political Thinkers from Hobbes to Marx, Blackwell, Oxford, Malden and Massachusetts.

Held, D (1989) Political Theory and the Modern State Essays on State, Power and Democracy, Standford University Press, California

Hobbes, T. [1651] (1894) LEVIATHAN, The Matter, Form and Power of a Commonwealth, Ecclesiastical and Civil, Fourth Edition, George Routledge and Sons: Manchester and New York.

Levine, A. (2002), Engaging Political Philosophy from Hobbes to Rawls, Blackwell, UK

Locke, J. (1823) Two Treaties of Government, from The Works of John Locke. A New Edition, Corrected. In Ten Volumes. Vol. V.: McMaster University Archive of the History of Economic Thought: London

Locke, J. [1689], (2013) A Letter Concerning Toleration and Other Writings, Ed. By Mark Goldie, Liberty Fund, Indianapolis

Martel, J. (2016) “Hobbes' Anti-Liberal Individualism”, International Journal of Political Philosophy, Vol. 5, No.9 (2016), pp.31-59

McNeilly (1968), The Anatomy of Leviathan, Macmillan, New York

Owen, J.J. (2005) “The Tolerant Leviathan: Hobbes and the Paradox of Liberalism”, Vol. 37, (Jan 2005), pp. 130-148 
Pennock, J.R. (1960), “Hobbes' Confusing Clarity: The Case of Liberty” American Political Science Review, vol. 54, pp 428-36.

Rapaczynski, A. (1987), Nature and Politics: Liberalism in the Philosophies of Hobbes, Locke and Rousseau, Cornell University Press: Ithaca, NY

Raphael, D.D. (1990), Problems of Political Philosophy, Second Edition, revised and enlarged, Macmillan Press: London and Hong Kong

Russel, B. (1996), Batı Felsefesi Tarihi, Say yayınları, İstanbul

Saraçoğlu, A. M. (2002), “Evrensel Özgürlük Alanının İnşaasini Y eniden Düşünmek”, Türkiye Günlügüu, Ankara, no. 68, s: 87-96.

Seliger, M. (1969), The Liberal Politics of John Locke, Frederick A. Praeger Publishers, New York

Schochet, J. (1990), "Intending (Political) Obligation: Hobbes and the Voluntary Basis of Society" in Dietz, M. G. (ed.) Thomas Hobbes and Political Theory, University Press of Kansas, Lawrence

Simmons, J. (1992), The Lockean Theory of Rights, Princeton University Press, Princeton, New Jersey

Sommerville, J. (1992), Thomas Hobbes: Political Ideas in Historical Context, Macmillan, London

Tully, J. (1993), An Approach to Political Philosophy: Locke in Contexts, Cambridge University Press, Cambridge

Zabc1, F. (2004), “John Locke: Liberalizmin Düşüncedeki Öncüsü” in Ağaoğulları, M. A.at all (ed.) Kral-Devletten Ulus-Devlete, İmge Yayınları, Ankara

Wolin, S. (1990), "Hobbes and the Culture of Despotism” in Dietz, M. G. (ed.) Thomas Hobbes and Political Theory, University Press of Kansas, Lawrence 